Available online at GSC Online Press Directory

GSC Biological and Pharmaceutical Sciences

e-ISSN: 2581-3250, CODEN (USA): GBPSC2

Journal homepage: https://www.gsconlinepress.com/journals/gscbps

(RESEARCH ARTICLE)

\title{
Study of zooplankton community structure for aquaculture planning in Lony dam reservoir
}

\author{
Mishra Yogesh * \\ Department of Zoology Bhavan's Mehta Mahavidyalaya Bharwari Kaushambi, Uttar Pradesh India.
}

Publication history: Received on 05 April 2020; revised on 12 April 2020; accepted on 15 April 2020

Article DOI: https://doi.org/10.30574/gscbps.2020.11.1.0087

\begin{abstract}
Zooplanktons form an important intermediary step in the grazing food chain in aquatic ecosystem. The qualitative analysis of zooplankton has shown that the rotifers, protozoans, cladocerans and copepods were the major components of its total bulk in lony dam. The maximum magnitude of zooplanktons abundance was found in summer months and minimum was noted in early monsoon months. The study includes 28 species of zooplanktons which shows its moderate bio-diversity. The remarkable seasonal changes of total zooplanktons at present water body were registered. The littoral stations had high zoo planktonic density than limnetic sites. The quantitative variability of zooplankton has highlighted their mesotrophic nature. The mean maximum and minimum values of zooplanktons were recorded.
\end{abstract}

Keywords: Biodiversity; Food chain; Littoral and limnetic sites; Mesotrophic

\section{Introduction}

Zooplanktons usually act as primary consumers and constitute an important link between primary producers and higher consumers in aquatic food chain. Zooplanktons are used as fish food and other macro fauna. More than $75 \%$ of freshwater fish feed on plankton at one or other stage of their life cycle.

Phytoplanktons are the main source of food directly or indirectly to the fish population. The zooplankton and other micro invertebrates also depend upon phytoplankton for their existence. Zooplankton is considered to be the ecological indicators of water bodies (Gajbhiye and Desai, 1981). The availability of zooplankton as food for larval fish is thought to be one of the key factors that strengthen commercial fisheries (Kane 1993). Phytoplankton and zooplankton together constitutes the natural fish food organisms. High plankton counts indicate high fish production potential (ICAR 2011).

Zooplanktons are very common in pelagic and littoral regions of the water. The present study includes zooplanktons of protozoa, rotifer, cladocera, copepod and ostracoda. The protozoan zooplanktons include flagellates, ciliates and sarcodines. The flagellates are the most abundant among protozoan zooplankton. They include dinoflagellates, chrysomonads, euglenoids, volvocids, choanoflagellates and large group of heterotrophic flagellates. The ciliates include oligotriches, hypotrichids and tintinnids. Sacrodines are poorly found in freshwater. Rotifers are minute animals. They form the most important metazoans among planktons. Cladocerans form the most useful nutritive group of crustaceans for higher member of fishes in the food chain. They are covered by chitins covering and have two large antennae. The copepods also considered as fish food. The ostracodes are bivalve organisms of phylum arthopoda. They are also consumed by fishes and benthic macro invertebrates.

\footnotetext{
${ }^{*}$ Corresponding author: Mishra Yogesh
} 


\section{Material and methods}

The study was carried out at loni dam ( $\left.81^{0} 34^{\prime} 10^{\prime \prime}\right)$ which is situated near suti village, teonthar tehsil, Rewa M. P. This site is located at the Prayagraj to Rewa road at national hi way no-27. Monthly samples were collected following the composite sampling technique (Gomez and Gomez, 1984).Water sample for zooplankton study was collected from four sampling sites. Site A and B from littoral zone and site C and D from limnetic zone were selected. The samples were collected in clean and dried bottles in every month from July to June in 2017-18 and 2018-19. All samples were collected between 7:30am-9:00am. Plankton samples were preserved in phosphate buffered formalin at 3\% concentration with one drop of glycerine (Gupta and Dey, 2012). Planktons were identified up to generic level from APHA (1998), Needham and Needham (1962), Battis (1992), Bellinger (1992), and Vuuren et.al. (2006). Now the preserved sample was kept for 24 hours for sedimentation. After decanting water carefully the samples were centrifuged and about $50 \mathrm{ml}$ was collected for every sample. The samples from different stations were mixed and again centrifuged to get the total volume about $10 \mathrm{ml}$.The quantitative analysis of zooplankton was done with the help of Sedgwick rafter counting cell and lackeys drop method (APHA, 1998) and it was classified under protozoa, rotifer, cladocera, copepod and ostracoda . One drop of the sample was taken and transferred it on the slide. The whole drop was covered with the cover slip. Now all the zooplankton was counted in the drop.

To calculate the number of organisms per liter the following formula was used

\subsection{Sedgwick-rafter cell Method}

$$
\operatorname{Organism} \text { per liter }(\mathrm{N})=\frac{\mathrm{R} \times 1000 \mathrm{~mm}^{3} \times 10^{3}}{\mathrm{~L} \times \mathrm{D} \times \mathrm{W} \times \mathrm{S}}
$$

Where, $\mathrm{R}=$ number of organisms counted per subsample

$\mathrm{L}=$ Depth of a strip, $\mathrm{mm}$

$\mathrm{W}=$ width of a strip, $\mathrm{mm}$

$\mathrm{S}=$ Number of strips counted

Therefore, Total organisms per liter $=\mathrm{N} \times 1 / \mathrm{C}$

$$
\text { Where concentration factor } \mathrm{C}=\frac{\text { Volume of original sample }(\mathrm{ml})}{\text { Volume of concentrated sample }(\mathrm{ml})}
$$

\subsection{Lackey's drop method}

$$
\operatorname{Organism} \text { per liter }(\mathrm{N})=\frac{\mathrm{R} \times \mathrm{At} \times 10^{3}}{\operatorname{As} \times \mathrm{S} \times \mathrm{V}}
$$

Where $\mathrm{R}=$ Number of organisms counted per subsample

A $\mathrm{t}=$ Area of cover slip, $\mathrm{mm}^{2}$

A $s=$ Number of one strip, $\mathrm{mm}^{2}$

$\mathrm{S}=$ Number of strips counted, and

$\mathrm{V}=$ Volume of sample under the cover slip, ml

Therefore, Total organisms per liter $=\mathrm{N} \times 1 / \mathrm{C}$

$$
\text { Where concentration factor } \mathrm{C}=\frac{\text { Volume of original sample }(\mathrm{ml})}{\text { Volume of concentrated sample }(\mathrm{ml})}
$$

\section{Results and discussion}

\subsection{Zooplankton diversity}

Species composition of zooplankton at different experimental sites during 2017-18 and 2018-19 are belonging to four taxonomic groups of Protozoa, Rotifer, Cladocera and Copepod. 
Table 1 Seasonal mean values of two years- 2017-18 and 2018-19 of Zoo planktonic species of Loni Dam at different sites

\begin{tabular}{|c|c|c|c|c|c|c|c|c|c|c|c|c|c|}
\hline \multirow{2}{*}{ Sl No. } & \multirow{2}{*}{ Name of species } & \multicolumn{3}{|c|}{$\mathbf{A}$} & \multicolumn{3}{|c|}{ B } & \multicolumn{3}{|c|}{$\mathbf{C}$} & \multicolumn{3}{|c|}{ D } \\
\hline & & Rainy & Winter & Summer & Rainy & Winter & Summer & Rainy & Winter & Summer & Rainy & Winter & Summer \\
\hline & Protozoa & & & & & & & & & & & & \\
\hline 1 & Euglyphasp & 10.5 & 7.5 & 15 & 10 & 6.5 & 13.5 & 5 & 5.5 & 7 & 7 & 6.5 & 6 \\
\hline 2 & Diffugia $s p$ & 20 & 15.5 & 28.5 & 21.5 & 15 & 26 & 17.5 & 13.5 & 18 & 15.5 & 11.5 & 15 \\
\hline 3 & Actinophrys sp & 10 & 7.5 & 12.5 & 13 & 16 & 12.5 & 8 & 8 & 12.5 & 8 & 8 & 13.5 \\
\hline 4 & Paramecium sp & 27 & 28.5 & 37 & 25 & 24.5 & 31 & 20.5 & 17.5 & 21.5 & 18.5 & 15 & 23 \\
\hline 5 & Vorticella sp & 21.5 & 18 & 29.5 & 17.5 & 17 & 29 & 19 & 14 & 17.5 & 18 & 13 & 15.5 \\
\hline \multirow[t]{2}{*}{6} & Arcella & 18 & 13.5 & 20.5 & 19 & 10 & 20.5 & 9 & 10 & 13 & 9 & 8.5 & 11.5 \\
\hline & Rotifera & & & & & & & & & & & & \\
\hline 7 & Brachionus quadridentatus & 19.5 & 9 & 17.5 & 22 & 9 & 24.5 & 12.5 & 8 & 16.5 & 12 & 8.5 & 15.5 \\
\hline 8 & B. patulus & 19 & 11 & 18.5 & 17 & 9.5 & 16.5 & 12 & 8.5 & 18.5 & 11.5 & 7.5 & 16 \\
\hline 9 & B. rubens & 18 & 9 & 21.5 & 20.5 & 9 & 19.5 & 20.5 & 10.5 & 30 & 26 & 10 & 28 \\
\hline 10 & B. caudatus & 45 & 17.5 & 32.5 & 49 & 17 & 30.5 & 23 & 10 & 22.5 & 30 & 11.5 & 19 \\
\hline 11 & B. angularis & 37 & 22 & 43.5 & 39.5 & 21 & 43.5 & 24.5 & 16 & 33.5 & 16.5 & 14.5 & 26.5 \\
\hline 12 & Polyarthra sp & 26 & 20.5 & 35 & 24 & 21 & 37 & 15.5 & 9 & 16 & 18 & 9.5 & 15 \\
\hline 13 & Trichocera sp & 16 & 12 & 25.5 & 15 & 12 & 28.5 & 18 & 8.5 & 11.5 & 19 & 10.5 & 15 \\
\hline 14 & Asplanchna sp & 11 & 8 & 19.5 & 14.5 & 8 & 20 & 15.5 & 10.5 & 13.5 & 14.5 & 12 & 13 \\
\hline 15 & Keratella sp & 21 & 13.5 & 25 & 22.5 & 11.5 & 25 & 16 & 9.5 & 17 & 15.5 & 9.5 & 18 \\
\hline 16 & Rotaria sp & 11.5 & 10 & 15 & 12.5 & 9 & 13.5 & 26.5 & 9 & 13.5 & 21.5 & 10 & 11.5 \\
\hline \multirow[t]{2}{*}{17} & Monostyla sp & 17 & 12.5 & 28 & 19 & 12.5 & 26.5 & 16 & 9 & 15.5 & 15.5 & 8.5 & 11.5 \\
\hline & Cladocera & & & & & & & & & & & & \\
\hline 18 & Alona sp & 14 & 10 & 22.5 & 14.5 & 6 & 21 & 4.5 & 5 & 11 & 6 & 4.5 & 8 \\
\hline 19 & Chydorus sp & 14 & 9 & 18 & 14 & 7.5 & 18.5 & 5.5 & 6 & 11.5 & 7 & 5 & 10 \\
\hline 20 & Moina sp & 18.5 & 12 & 20.5 & 19 & 9 & 18.5 & 13 & 10.5 & 10 & 13 & 8.5 & 10 \\
\hline 21 & Daphnia sp & 19 & 12.5 & 26 & 18 & 12.5 & 28 & 22.5 & 8 & 16.5 & 21.5 & 9.5 & $` 14$ \\
\hline 22 & Moinodaphnia & 18 & 12.5 & 22.5 & 17 & 11.5 & 21 & 4 & 12.5 & 26 & 4 & 21 & 31.5 \\
\hline \multirow[t]{2}{*}{23} & Pleuroxus sp & 11.5 & 8 & 20.5 & 12 & 6.5 & 19 & 6 & 5.5 & 4.5 & 4.5 & 5 & 8.5 \\
\hline & Copepoda & & & & & & & & & & & & \\
\hline 24 & Cyclops & 11.5 & 9 & 12 & 10.5 & 7 & 11.5 & 6 & 4 & 6 & 4 & 4.5 & 7 \\
\hline 25 & Paracyclops & 7 & 8 & 13.5 & 7 & 7 & 10.5 & 3 & 4 & 5 & 4 & 5 & 5 \\
\hline 26 & Daptomus sp & 7 & 8 & 11 & 6 & 7.5 & 10.5 & 2.5 & 3.5 & 3.5 & 3.5 & 4.5 & 4.5 \\
\hline 27 & Clenoid sp & 8.5 & 7.5 & 11 & 8 & 6 & 11 & 5.5 & 4 & 4.5 & 3.5 & 4.5 & 5.5 \\
\hline 28 & Nauplius larvae & 9.5 & 8.5 & 9.5 & 12 & 8.5 & 8.5 & 11 & 7.5 & 6.5 & 9.5 & 7 & 7.5 \\
\hline
\end{tabular}


Out of 28 species 6 belongs to Protozoa, 11 to Rotifer, 6 to Cladocera and 5 to Copepod (table1). The qualitative and quantitative changes in phytoplankton and zooplankton are usually affected by a number of physicochemical and biotic factors. Singh (1986) reported that freshwater temperature affects the movements of zooplankton to great extent. It is also evident from present investigation that physic-chemical and biological factors govern the seasonal and spatial abundance of zoo biota. The protozoan species of present water have shown a remarkable seasonal variation and biodiversity. Their spatial changes were also documented to be notable. Moreover the protozoans were recorded with a bimodal peak, the first peak in summer and second one in winter. A sudden decline was found in monsoon month.

\subsection{Zooplankton Count}

The rotifers exhibited bimodal peak, first peak in summer and second one in winter with 11 species. It indicates the fact that high temperature and $\mathrm{pH}$ favors the growth of rotifers. According to George $(1966,1969)$, Michael continuous (1968), Moitra and Bhowmik (1968) most of the rotifers fluctuate with a bimodal peak which appear in post monsoon season with a distinct seasonal succession. The rotifer species Namely Brachinous quadridentatus, B.patulus, B.rubens, B.caudatus, B.angularis, Polyarthra sp., Tricocera sp., Asplanchna sp, Keratella sp, Rotaria sp and Monostylla sp, were noted to be most common and dominating species in present water body. The species of B. angularis, B. caudatus, Polyarthra sp. and Monostylla sp. have contributed the major rotifer population. Among Rotifers angularis showed maximum species composition at all sampling sites while Asplanchna sp. showed minimum species composition at most sampling sites. Most of the rotifers fluctuate with bimodal peaks which appear in post monsoon season with a distinct seasonal succession. The present study has revealed that rotiferan densities depend on the quantitative changes of organic decaying materials and temperature. Among cladocerans the members of Daphnia sp., Moinodaphnia, Moina sp, Pleuroxus sp, Alona sp, and Chydorus sp, was very common species. It was dominated by Daphnia, Moinodaphnia and Moina species. Among Cladocera Daphnia sp. showed maximum species composition at all sampling sites during all seasons. The Pleuroxus sp. showed minimum species composition approximately all the sampling sites. Among copepod member's nauplius larvae, Clenoid sp, Cyclops, Para Cyclops and Daptomous sp were found to be common appearance with a wide range of distribution in littoral and limnetic water of lony dam. Among Copepods Cyclops sp. showed maximum and Daptomus sp. minimum species composition at most sampling sites during all the seasons. Species diversity values were found higher for rotifer and it is followed by protozoa, cladocera and copepod. All four groups showed higher values of species diversity during summer season. The qualitative analysis of zooplankton has shown that the rotifers, protozoans, cladocerans and copepods were the major components of its total bulk in lony dam. The maximum magnitude of zooplanktons abundance was found in summer months and minimum was noted in early monsoon months. Chaurasia and Adoni (1985) have noted pH and water temperature as the most valuable factors affecting the zoo planktonic density at Sagar Lake. It coincides with the present data. As the number of species concerned the major groups of zooplankton have shown the dominating trend indicating the pattern of biodiversity are Rotifera > Protozoa > Cladocera > Copepoda. The mean maximum values of total zooplankton were 225.0 units/L and 179.5 units/L while minimum values were observed 78.0 units/L and 50.3 units/L in 2017-18 and 2018-19 respectively. The qualitative assessment of zoo planktonic species and their seasonal abundance and distribution is not only indispensable in food chain mechanism but is also significant in bio-monitoring of fresh water bodies. According to Alikundi et al. (1955), Das and Shrivastava (1959), Moitra and Mukherjee (1972), Datta et al. (1987) and Singh (1990), Fuller (1977), the variability of zoo planktonic species with seasons and sampling sites are important bio-indicatives in predicting the trophic nature of water.

\section{Conclusion}

The protozoa with 6 species have shown higher number in June and July months and lowest in monsoon season. Their densities were noted to be higher at littoral sites. The species of paramecium, Vorticella and Euglypha found to be contributing the main bulk of protozoans which had wide range of distribution. However Actinophrys was found to be rare. Among Protozoa paramecium showed maximum species composition while Euglypha showed minimum species composition at all sampling sites of Lony dam. The rotiferan have shown high magnitude of biodiversity in comparison to other subgroups with 11 species. The rotifer was mainly dominated by Brachionus species. The rotifers were recorded to be most dominating, abundant and widely distributed species in present water body. It is thus considered as an important bio-indicative in order to predict the polluted and deteriorating water conditions. Rotifers being among the smallest members of zooplankton are known to feed upon the smallest phytoplankton and detritus particles (Dhanapati 2000, Vuuren et al. (2006). The cladocerans were dominated by members of Daphnia sp and Moinodaphnia and Moina, While Copepods were dominated by Cyclops, Clenoids and nauplius larvae. 


\section{Compliance with ethical standards}

\section{Acknowledgments}

The author express his indebtedness and heartfelt gratitude to Dr. D. N. Jha, senior scientist, regional centre ICAR, Central Inland Fisheries Research Institute, Prayagraj for their intellectual inputs and sophisticated guidance for carrying out the research work. The author is thankful to Dr. R. K. Pandey Head of the Department (Zoology), KNI P.G. College, Sultanpur U.P. and Dr. R. K. Pathak, Department of Zoology, Allahabad Central University for their comments on the manuscript. The importance of present study is to help fish farmers to chalk out strategies for fish culture enhancement programs in future. References

\section{References}

[1] Gajbhiye SN and Desai BN. (1981). Zooplankton variability in polluted and unpolluted waters of Bombay, Mahasagar. Bulletin of National Institute of Oceanography, 4, 173-182.

[2] Kane J. (1993). Variability of zooplankton biomass and dominant species abundance of Georges Bank (19971986). Fisheries Bulletin, 3, 464-474.

[3] ICAR. (2011). Handbook of Fisheries and Aquaculture, ICAR pub., New Delhi, 5, 43-45.

[4] Gomez KA and Gomez AA. (1984). Statistical procedures for agricultural research, 2nd edition, Wiley-Inter Science, New Yark, 680.

[5] Gupta T and Dey M. (2012). Hydro biological characteristics of some semi intensive fish culture ponds of Lumding town of Nagon district, Assam. Current World Environment, 8(1), 30-39.

[6] APHA. (1998). Standard methods for examination of water and waste water, 20th edition, American Public Health Association, AWWA, WPCA, Washington, D.C., U.S.A. 1193.

[7] Singh DF and Rai MK. (1988). Studies on the limnology of bada talab Chhindwara MP, J. Environ Biol., 9(i) 69-71.

[8] Michael RG. (1968). Studies on the Zooplankton of a tropical fish pond Hydrobiologia, 23-68.

[9] Moitra SK and Bhattacharya BK. (1965). Some hydrological factors affecting plankton production in a fish pond in Kalyani W. Bengal India, Icthyological, IV (1-2), 8-12.

[10] Chaurasia and Adoni AD. (1985) .Workbook on limnology, Pratibha Publishers Sagar, India 216.

[11] Dhanpati MVSSS. (2000).Taxonomic notes on the rotifers from India (1889-2000). Indian Association of Aquatic Biologist (IAAB), Hyderabad.

[12] Vuuren JVS, Taylor J, Gerber A and Ginkel CV. (2006). Easy identification of the most common freshwater algae: A guide for the identification of microscopic algae in South African freshwaters: North-West University and Depth of Water Affairs and forestry South Africa, 17-192.

\section{How to cite this article}

Mishra Y. (2020). Study of zooplankton community structure for aquaculture planning in Lony dam reservoir. GSC Biological and Pharmaceutical Sciences, 11(1), 161-165. 